\title{
The concept "God" (case study: phraseological units in the English, Russian, Tatar and Turkish languages)
}

\author{
L.V. Bazarova ${ }^{1}, A . A$. Bilyalova $^{1, *}$, R.D. Shakirova ${ }^{2}$ \\ ${ }^{1}$ Kazan Federal University, 420008, Kazan, Russia \\ ${ }^{2}$ Naberezhnye Chelny State Pedagogical, 423806, Naberezhnye Chelny, Russia.
}

\begin{abstract}
The concept is represented as a unity of perceptions, representations, and assessments existing in the communal and individual linguistic consciousness and can be expressed at all language levels, characterizing English, Russian, Tatar and Turkish linguocultures and revealing unique and universal features. The sphere of concepts of each national culture has a number of its unique and distinctive features, expressed in the representation of God. In English, Russian, Tatar, Turkish linguocultures some of the described features can be considered as a part of a conceptual component, but in some cases, they are completely absent. On the periphery, there is a visual image of God, which proves the fact that concepts of God in the researching cultures are in some way different. The phraseological unit scope of the concept "God" contains the conceptual "soul", "fate", "goodness", "light" which serve to fully understand and reveal the semantic structure of the concept being studied.
\end{abstract}

\section{Introduction}

The presence and functioning of word-nominations of different concepts in the lexical and phraseological environment play an important role in characteristics of any culture [1]. V.V. Vinogradov notes that "the full meaning of the semantic structure of the word, that is, not only its primary meaning, but also a set of meanings with expressive and stylistic shades, and also its "internal" forms, is possible only within the background of the entire lexical system and in connection with it" [2, p.6]. The whole picture of the world inherent to a certain people is fixed and reflected in the language and its surroundings, first of all, in those aspects of the language - in phraseological units (PUs) - that reflect the views of people developed over the centuries [3].

In the given paper we studied the correlation of the phraseological concept "God" with the conceptual "goodness", "soul", "fate" in English, Russian, Tatar and Turkish.

We agree with I.P. Susov, A.I. Fefilova, E.S. Palekh, who use the term "conceptual" due to its etymological connection with broader notions as a concept, sphere of concepts, and also due to its involvement in the system of the metalanguage of linguistics. The conceptual as a unit-level of semantics is a structure of thought, the organization of mental concepts [4, p.213].

The study of the concept of "God" in correlation with the conceptual "goodness", "soul", "fate" and "light" helps to identify national and cultural specificity in English, Russian, Tatar and Turkish and can make the dominant value-evaluation of semantic meanings which are used verbally. The analyzed conceptuals are key points for the disclosure and understanding of ideas about breadth, richness and various manifestations of the inner world of a person in a particular linguistic culture and their attitude to the conceptuals being studied [5].

In order to reveal the meaning of the concept "God", it seems necessary to analyze the meaning of each conceptual - "soul", "fate", "goodness", "light", and also to reveal their allomorphic and isomorphic features. It is also important to structure the revealed phraseological units of the English, Russian, Tatar, and Turkish languages by thematic groups.

\section{Research Methodology}

The material of the survey consists of 1700 English, 2245 Russian, 1400 Tatar and 1653 Turkish phraseological units. They were selected by the method of continuous sampling from English, Russian, Tatar and Turkish phraseological dictionaries and reference books, also from paremiological, synonymous, etymological dictionaries. We have studied texts of informants' questionnaires, the total number of which is 453 (86 questionnaires are English native speakers, 150 Russian, 112 questionnaires are native speakers of the Tatar language and 105 of Turkish speakers. The case of lexicographic sources sampling is more than $150 \mathrm{PU}$ (44 examples from English, 74 from Russian, 17 from Tatar and 15 from Turkish).

The examining of the material which was obtained by continuous sampling carried out using the

* Corresponding author: abill71@mail.ru 
methods of conceptual, component, etymological analysis; descriptive method, including methods of observation, interpretation, comparison, and generalization, and elements of the statistical method.

\section{Study and Discussion}

The conceptual "soul" is one of the key abstract conceptual and moral, ethical categories that form the linguistic picture of the world, which is fixed and preserved in the national mentality. It is worth noting here that in many scientific papers of Russian linguists the word "soul" is identified with the word "spirit".

V.V. Kolesov writes about the following division of these conceptuals. He believes that "soul" reflects the emotional experience, and "spirit" is the creative upgrade. However, the most important thing is the symbolic correlation between "soul" and "spirit", which creates not only the meaning of each word but also the deep essence of their meanings, their ideologically important significance [6, p.172]. According to V.N. Lossky, "spirit" has the supreme capacity of intelligent soul, the ability by which a person enters into communion with God, but "soul", in its turn, is nourished by the spirit [7, p.97]. In English, these conceptuals are also clearly defined: the English word "soul" is used to refer to the immaterial essence of the person, living in his body, whereas "spirit" refers to the highest degree of the essence of personality. In the Tatar and Turkish languages "soul" and "spirit" are closer in meaning. Consequently, "soul" is separate and individual, and "spirit" mostly is a part of some interpersonal substance.

In our work, we stick to the definition of Yu.S. Stepanov, who underlines the differences that exist between the conceptuals "soul" and "spirit". The researcher notes that "the conceptuals "soul" and "spirit" are clear enough when the spirit means the highest capacity of the soul through which a person enters into communion with God" [8, p.720]. This idea of the soul as capable of contact with God with the help of the spirit can be defined as a supernatural, immaterial immortal beginning in a person who continues to live after his death and it is reflected in the phraseology of English, Russian, Tatar and Turkish.

It is crucially important in our research to consider not so much the difference between these concepts but the correlation between the conceptual "soul" and the concept "God" on the material of phraseological units of different languages.

In the analysis of the linguistic material we have found out that for the verbalization of the concept "soul" in the nominative meaning in English, the word "soul" is used, in Russian the word "dusha", in Tatar - "zhan / rukh', in Turkish - "can"; in the figurative meaning in English we used "heart", "mind", "life", "spirit"; in Russian - "serdce'; in Tatar - "kunel", "jorek"; in Turkish - "gönül”, "yürek”.

The following common meanings of words verbalizing the concept "soul" were found in the studied languages: the immaterial part of a person that is believed to exist forever; the spirit of the deceased person freed from the bodily shell; inner mental world of a person, including emotions, feelings, will, character; the man himself; a part of God, spiritualizing human body. In turn, the figurative meanings of the conceptual "soul"/“dusha"/"zhan"/"can" express the location of emotions, affection, love; features of character; sensitivity, ability to sympathize; moral nature or conscience; will or propensity; spirit, courage, enthusiasm; man; conscience, soul, heart, mind; innermost thoughts and feelings; psyche, soul. However, we share the meaning of the conceptual "soul", which reveals the essence of this concept concerning the concept "God", namely God or his divine nature, manifested in man: V kom dusha, v tom i Bog [9].

To reveal the content of the conceptual "soul" the meanings of the words presented in the phraseological units of the English, Russian, Tatar and Turkish languages were analyzed. The basic meaning of the soul is an intangible part of a person, which continues to exist in some form after his bodily death. This understanding of conteptual "soul" we can find in the following phraseological units: Eng. to lose one's soul, yeld up the soul [10]; Rus. zagubit' dushu, prodat' dushu <d'yavolu>, dusha vyshla [11]; Tat. zhan biru [12]; Turk. canını şeytana satmak, canına rahmet! [13]. The conceptual "soul" in this sense is represented in the studied languages by direct matches of nominative meanings of the words "soul"/"dusha"/"zhan"/“can". Consequently, the conceptual "soul" consists of certain mental preferences in the spiritual and moral aspect and is semanticized by such components as "the gift of God", "the living entity with mind and will", "the inner essence of a person", "the criterion of moral assessments". Soul is understood as an ideal entity through which a person is connected with God.

The specificity of the correlation between the next studied conceptual "fate" and the concept "God" is in defining the axiological conceptual "fate" as an important marker of national mental space, representing the center of human spiritual life, the receptacle of feelings, moods, thoughts, will, religious beliefs and as a nuclear component of the taxonomic model, dictating its features [14]. Of particular interest is the interpretation of the conceptual "fate" and the objectification of this language level in phraseological units. In English this conceptual is expressed by the word "fate", in Russian "sud'ba", in Tatar - "jazmysh", in Turkish - "kader". At the periphery are units that have common with the core of the lexeme "fate": destiny, chance, fortune - in English; rok, sud'ba, sluchaj, fortuna - in Russian; tekdir, felek, mokader, olesh, felyakh, kureček - in Tatar; kismet, talih, felek - in Turkish.

The lexeme "fate" in the studied languages is used in meanings that form different worldview positions. In one case, "fate" means a deterministic force over which a person does not have power. In the second case, this lexeme can indicate an already established sequence of events in someone's life. In the study, the more acceptable meaning of the lexeme "fate" is the meaning that reveals the essence of the concept "God", i.e. fate as given to man by God. The unification of 
phraseological units according to the subject matter reflects the existing groupings of objects and phenomena of the surrounding world.

In the context of this study, we draw attention to the thematic group "Man is the master of his fate". The meaning of this thematic group is reduced to the fact that fate depends on a person himself, and only the person must influence his destiny. This meaning is reflected in the following phraseological units: Eng. God helps those who help themselves, Trust in God but rely on yourself [15]; Rus. Na Boga upovaj, a bez dela ne byvaj!; Kto rano vstaet, tomu Bog podaet; Budesh' ploh, ne dast $i$ Bog; Bogu molis', a sam ne ploshis'; Tat. Alladan omet itme, uzennon omet it; Allaga yshan, uzen kymshan; Turk. Tencere tava, herkeste/hepsi bir hava; Kişinin iradesi Allah elindedir. In the linguocultures under our consideration, success, happiness, destiny are directly connected with the efforts of the individual. The phraseological units of this group focus a person on activity, encourages a person not to rely on higher forces, but to rely on himself.

The next thematic group is "Fate as given to man by God". Researcher A. I. Vakhrusheva notes that "historically the concept of fate is connected with the concept "God" through the concept of divine judgment" [16, p.298]. Fate and God are objects of faith; they denote the power endowed with authority. Fate, in turn, governs a man, God governs the whole world. God and fate in the researched pairs do not play the role of synonyms, it is important to note here that people's conscience gives God the qualities of fate. PUs of this group reveals the meaning of subordination that is the dependence of man's fate on the deity: Rus. Chto budet, to budet; a budet to, chto Bog dast; Bog ne rodit, $i$ zemlya dast; Chego Bog ne nashlet, togo chelovek ne poneset; Tat. Aldagysyn Alla bele [17]; Turk. Allah dokuzda verdiğini sekizde almaz; Allah bilir işini.

It should be noted that the existence of higher forces that impart fate to a person is beyond doubt. On the one hand, fate does not depend upon man's desires and often disagrees with them. We can observe this meaning in the following PUs: Rus. Ne tak by hotelos', da tak Bog velel; Turk. Allahtan yazılmış başa gelecek. On the other hand, fate can depend on man's desires and provides a choice in cases when a person is guided by truth, charity, goodness: Rus. Milostivomu cheloveku $i$ Bog podaet; Bog tomu dast, kto pravdoj zhivet; Kto dobro tvorit, tomu Bog oplatit/blagoslovit; Turk. Iyilik et denize at ballk bilmezse Halik/Allah bilir. As a result, fate from an active figure passes to passive, thereby influencing fate. In the case of the right choice a person is provided with prosperous fate: Rus. Glupomu schast'e, umnomu Bog daet; Tat. Adem unsa uzennen, unmasa tekdirennen kurer; Turk. Allah sabırlı kulunu sever.

The next studied conceptual "goodness" is one of the few conceptuals that plays a significant role in revealing the meaning of the analyzed concept "God", appearing in many religious and philosophical systems as the fundamental beginning of human being where the accomplishments of God are infinitely close to goodness. The conceptual "goodness" enters the core of the linguistic consciousness of different peoples, which provokes interest for linguistic and individual realization of the key meaning of moral consciousness. The conceptual "goodness" is presented in English by the basic lexeme "good", in Russian - "dobro", in Tatar "yakhshylyk/igelek", in Turkish - "iyilik". Based on lexicographic sources, it is advisable to identify the most significant definition of the concept. V.I. Dal distinguishes the definition close to our study, in the disclosure of the concept "goodness". The researcher considers goodness as "spiritual value, the benefit that is fair and useful, it is all that demands from us the duty of a man, a citizen, a family man". In this definition, it is emphasized that goodness comes from God, who gives a person goodness and focuses a person on goodness. Thus, in the word combination "to create goodness" we mean "to commit moral acts, which have explicit social value". In the system of ethical values, they occupy a strong position, that's why in proverbs they relate to God: Rus. Kto dobro tvorit, tomu/togo Bog oplatit/blagoslovit; Za dobro Bog platel'shchik; Tat. Yahshylyk kyl, dor'yaga sal: balyk belmese, halyk/Alla beler; Turk. Iyilik et denize at, ballk bilmezse, Halik/Allah bilir. It is also emphasized that the person who does goodness receives recompense from God: Rus. $S$ bogom pojdesh', do blagogo dojdesh'; Dobrym putem Bog pravit; Tat. Yahshylyk itsen, Alladan kajtyr; Turk. Iyilik eden Allahtan iyilik bulur.

A person who creates goodness is characterized by a special involvement in God, for which God gives salvation. In the studied cultures, goodness is identified with mercy, namely, with condescending love, pleasant attitude, desire to forgive someone, benevolence, bounty, grace: Rus. Velik Bog milost'yu; Milostivomu cheloveku $i$ Bog podaet; Tat. Yahshylyk itsen, Alladan kajtyr; Turk. Allah doğrunun yardımcisıdır. Consequently, conceptual "goodness" is perceived as something warm and bright, a verbalized associate. From a religious point of view, the conceptual "goodness" is a way to absolute goodness - deity, associated with the ideas of spiritual entities present in the world, supernatural forces, benevolent to the person, promoting human happiness and well-being.

In turn, "light" is a concept that carries a positive connotation from the very beginning of its appearance. "Light" is defined as a vast, bright, habitable space necessary for a person to live. This understanding of light is reflected in folk traditions, myths, religious beliefs, in the language and in the consciousness of modern man. In the religious representation, light is the symbol of God, the divine, holy, faith. This opinion is confirmed by the definition given by the dictionary of symbols, where it is noted that the light is synonymous with God in both the Orthodox, Protestant religions, and in Islam: Allah is the light of heaven and earth.

In this study, it seems necessary to turn to the analysis of lexicographic sources to identify hidden, stable semantic features and connotations, which are behind the concentrated experience of previous generations, culture, religion and mentality of the whole nation, the carrier of a particular linguistic consciousness. This statement is valid with respect to the concept of "light" implemented in the linguistic space, presented in English as the lexeme "light", in Russian - 
"svet", in Tatar - "yaktylyk" / "dunya yze", in Turkish “1şık"/"ziya"/"aydınlık".

It seems possible to distinguish between phraseological units representing the concept "God" in the semantic section "light created by higher powers". The phraseological units in which this view of the world is presented contain ontological information; everything on Earth is created by some higher authority. This area is characteristic of the Russian language from the studied structural languages: God is a light from the beginning of the world; by God's will, the light is standing, science is living. Light is a kind of higher power, able to see and offend, i.e. to execute judgment on people. Playing an important role in the cognitive mechanism of knowledge of the world, this study helps to recreate the idea of light that exists in minds of Russian speakers as a symbol of God, holiness, divine knowledge, infinite goodness, purity, eternal life, characterized by positive connotation, which are significant for the language community and are not identified in other linguocultures.

\section{Results}

The conceptual "soul" explores certain mental preferences in the spiritual and moral aspect and is semanticized by such components as "God's gift", "the living entity with mind and will", "the inner essence of a man", "the criterion of moral assessments". Soul is understood as an ideal entity through which a person is connected with God.

The study of lexicographic sources and phraseological units leads to the conclusion that the concept of "fate" occupies a special place and has a lot in common in the analyzed languages, which is explained by the similarity of ways of thinking. Particularly noteworthy is the fact that the study identified the following thematic groups of the conceptual "fate" in the analyzed languages, namely "Man is the master of his fate", "Fate is given to man by God". It should be noted that these groups on the specifics of their usage coincide and are more of dictionary values. The analysis of the semantic meaning of the conceptual "fate" in lexicographic practice and in phraseological units leads to the emergence of semantic shades that can be represented in the form of oppositions: fate and will; constancy and variability of fate; happy and unhappy fate; just and unjust fate. The analysis of this conceptual is connected not only with the description of internal factors that implement the concept, but also the identification of the correlation with the nearest concept - in particular, with the concept "God".

The conceptual "goodness" is involved in the implementation of the concept "God", expanding and clarifying the meaning structure of this concept and allowing identifying in its composition the global categories of national consciousness. It is worth noting the fact that the conceptual "goodness" is used in the studied phraseological units with words denoting ethical and aesthetic values and are characterized by positive connotation: truth, verity, justice.
The study of the concept of "light" made it possible to recreate ideas about the concept under study, which contribute to the nomination of the semantic layer - the phrase-semantic field "light created by higher powers".

\section{Conclusion}

The conceptual analysis of the English, Russian, Tatar and Turkish phraseological units allowed us to identify the key conceptuals of the concept "God", that is "soul", "fate", and "goodness". They are crucial for understanding the concept "God", as they play an important role in religious, ethical, emotional and moral life spheres and influence the evaluative activity of representatives of linguistic communities, form the centers of separate areas of phraseological and proverbial pictures of the world, reflecting the world outlook and everyday views of the native speakers.

The unity of the conceptual "soul" and the concept of "God" is reflected in the definition of soul as an intangible part of a person who continues to exist in some form after his physical death.

The conceptual "fate" appears as one of the central and significant units in the studied linguocultures. This state is proved by the diversity of phraseological units and highlighting the thematic groups in correlation with phraseological units of the concept "God". These thematic groups are "Man is the master of his fate", "Fate is given to man by God".

The conceptual "goodness" is actualized in the following definition: goodness comes from God, God gives people goodness and God directs the human to create goodness.

Light is understood as a kind of higher power capable of seeing and offending, administering judgment on people, which allows recreating the idea of light as a symbol of God, holiness, divine knowledge, boundless goodness, purity, eternal life.

\section{References}

1. L.V.Bazarova, IEJME, Religious ideas in contemporary pedagogy: the specificity of moral concepts of God in the Protestant, Orthodox and Islamic linguocultures, 11. 6. 1681-1689 (2016)

2. V.V.Vinogradov, RusInst., The History of Words: ab. 1500 words and word combinations and over 5000 related words, 1138 (1999)

3. N.A.Gumerovna, B.A.Anvarovna, SocSc., Verbal phraseological units of the Russian and English languages, 11 (15). 3734- 3737 (2016)

4. A.I.Fefilov, Sc., Introduction to Cogitology, 240 (2010)

5. L.V.Bazarova, PSPI, Concepts "God" and "Devil" in English, Russian, Tatar and Turkish Phraseological Units of Adjective Type, 2. 124-130 (2015)

6. V.V.Kolesov, The Concept of Culture: Image Concept - Symbol, 16. 30-40 (1992)

7. V.N.Lossky, Trib., The Mystical Theology of the Eastern Church, Issue 1. 90-97 (1991) 
8. Yu.S.Stepanov, Ac., Semiotics. Anthology, 702 (2001)

9. V.I.Dal, Astr., The Explanatory Dictionary of the Russian Language, 348 (2006)

10. A.V.Kunin, English-Russian Phraseological Dictionary, 1210 (2006)

11. V.I.Dal, Eksmo, Proverbs and Sayings of the Russian People, 640 (2008)

12. N.Isanbet, Tatar Phraseological Dictionary, 235 (2001)

13. A.N.Baskakov, Turkish-Russian Dictionary: 200000 words and word combinations, 960 (2006)

18.
14. L.V.Bazarova, The Comparative Analysis of Substantive Phraseological Units with the Component "God" in Russian, English, German, Tatar and Turkish, 6 (60). 69-71 (2016)

15. S.I.Lubenskaya, Russian-English Phraseological Dictionary, 1056 (AST-PRESS UNIGA, 2016)

16. A.I. Vakhrusheva, The Correlation between the Concepts "Destiny" and "God" (historical aspect), 298-301 (2002)

17. G.Kh.Akhatov, Tatar Phraseological Dictionary, 176 (1982) 